\title{
Cumhuriyet Dönemi Eğitim Politikaları ve Yabancı Eğitim Uzmanlarının Eğitim deki Etkileri (1923-1960)
}

\author{
Nurhayat Çelebia, Erdi Kazanci ${ }^{\mathrm{b}, \mathrm{c}}$
}

\section{Özet}

$\mathrm{Bu}$ araştırmada, Cumhuriyet dönemi eğitim politikaları ve yabancı eğitim uzmanlarının eğitimdeki etkileri incelenmiştir. Cumhuriyetin ilk yıllarından itibaren Osmanlı'dan devralınan bozuk eğitim yapısının yeni bir anlayışla düzenlenmesine ilişkin önemli çalışmalar yapılmıştır. Bu konuda yabancı eğitim uzmanların görüşlerinden de yararlanılmıștır. Araştırma, betimsel tarama modelinde olup doküman incelemesine dayanmaktadır. Araştırma sonuçlarına göre; Osmanlı'dan devralınan eğitim yapısını değiştirmek için yapılan eğitim reformlarının eğitim sistemine yansımaları bugün de tartışılan ve güncelliğini koruyan bir konudur.
Anahtar Kelimeler

Eğitim

Politika

Yabancı Uzmanlar

Eğitim Reformu

Makale Hakkında

Geliş Tarihi: 29.06.2021

Kabul Tarihi: 15.12.2021

Doi: 10.18026/cbayarsos.959346

\section{Educational Policies of the Republic Period and the Effects of Foreign Education Scholars on Education (1923-1960)}

\begin{abstract}
In this study, the educational policies of the Republic period and the effects of foreign education scholars on education were examined. Since the first years of the Republic, important studies have been carried out on the regulation of the corrupt educational structure inherited from the Ottoman a new understanding. In this regard, the opinions of foreign education scholars were also used. The research is in the descriptive survey model and is based on document analysis. According to the research results; the reflections of the educational reforms made to change the educational structure inherited from the Ottoman on the education system is a topic that is still discussed and kept up to date.
\end{abstract}

Keywords

Education

Political

Foreign experts

Educational Reforms

About Article

Received: 29.06 .2021

Accepted: 15.12 .2021

Doi: 10.18026/cbayarsos.959346

a Prof.Dr. Karabük Üniversitesi, Edebiyat Fakültesi,Eğitim Bilimleri Bölümü Başkanı. ORCİD:0000-0002-4241-5373

b Öğretmen , Üçevler Ortaokulu. ORCID: 0000-0002-1226-587X

c İletişim Yazarı: erdi.1989@hotmail.com 


\section{Giriş}

1911 yılından, 1923 yılı Cumhuriyet'in ilânına kadar olan süreçte, Osmanlı İmparatorluğu uzun süren ve neticede kaybedilen savaşlar sonucu yıkılma sürecine girmiş ve bu süreçte yeni bir devlet olarak Türkiye Cumhuriyeti kurulmuştur. Uzun yıllar süren savaşlar, memleketin maddi kaynaklarını eriterek, ekonomisini adeta yok etmiş; birçok eğitimli insan şehit olmuş veya sakat kalmıştır. Türkiye nüfusunun azalmış olması, şehirleşme oranının düşüklüğü insan kaynakları açısından dikkat çekicidir (Tezel, 2015). Bu dönemde, ülkemizdeki nüfusun çoğunluğu köylerde yaşamakta ve yeterli okul bulunmamaktadır. Halkın vergi yükleri de başka bir problem oluşturmaktadır. Cumhuriyetin ilk yıllarında bu olumsuzluklara rağmen eğitime büyük önem verilmiştir. Okul, öğretmen ve öğrenci sayılarının artırılması, yeni pedagojik yöntem ve ilkelerin uygulanmaya çalışılması ve eğitime ayrılmaya çalışılan maddi imkânlar ilk dikkat çekici atılımlardır (Dik, 2016; Kapluhan, 2012).

Cumhuriyet' in kurulduğu ilk yıllarda en önde gelen problem öğretmen açığıdır. "Korkunç bir öğretmen buhranı" vardır. 15.000 ilkokul öğretmeni bulunmakta, bu dönemde 49.000 ilkokul öğretmenine daha ihtiyaç olduğu tahmin edilmektedir (Kanad,1941). O zaman Türkiye'deki on üç öğretmen okulundan yılda yaklaşık 500 öğretmen mezun olmakta; bu öğretmenler ancak ölen, emekli olan ve istifa eden öğretmenlerin yerini doldurabilmekte idi (Antel,1939). Öğretmen problemini Gazi Terbiye Enstitüsü üzerinden somut bir biçimde anlatan Antel (1939), "1926'daki kuruluşundan 1937 yılına kadar Gazi Terbiye Enstitüsü'nden 380 öğretmen mezun verildiğini" ve bu sayının ihtiyacın çok uzağında olduğunu belirtmiştir. Aynı dönemde, üniversite ve yüksekokul sayısı 1923'te dokuz iken 1938'de 17'ye, üniversite öğrenci sayısı ise 1923'te 1914 iken, 1938' de 9558'e yükselmiştir. Cumhuriyetle birlikte eğitime ayrılan kaynaklar sürekli artmıştır. 1923'te genel bütçe yüz milyon liradan fazla olmasına rağmen Eğitim Bakanlığı bütçesi üç milyon lira olmuştur. 1930 yılı Eğitim Bakanlığı bütçesi, üç kattan fazla artarak yaklaşık on milyon lira olmuş, 1938 yılı incelendiğinde ise on altı milyon lirayı geçtiği görülmüştür (Demirtaş, 2008).

Cumhuriyetin ilk yılları bütçe açısından da sancılı bir dönemdir. Her yıl bütçenin yaklaşık \%20'si Osmanlı Devleti'nin dış borçlarını ödemek için ayrılmıştır. 1938 yılında bile 249.954.020 liralık toplam bütçeden Maarif Vekâletine 14.670.130 lira ayrılırken, Düyun-u Umumiye 'ye (Genel Borçlar) 50.738.390 lira ayrılmıştır. Maarif Vekâleti bütçesinin üç katından fazla para Osmanlı Devleti'nden kalan borçlara gitmiştir. Özellikle Fransa ve İngiltere tarafından yönetilen kaynak ve mal varlıklarımızı geri almak için Cumhuriyet yönetiminin sonraki dönemlerde bile ciddi harcama yaptığı görülmektedir. Örneğin: Tütün İdaresi 4 milyon frank, İstanbul Rıhtımlar İdaresi ise 40 milyon Frank'a yabancılardan geri alınmıştır (Cumhuriyet, 13 May1s, 1938).

Cumhuriyet ve sonraki eğitime ait problemler, sadece Cumhuriyet öncesi döneme ait sistem çarpıklıkları ve devralınmış yapı ile ilgili değildir. İmkânlar açısından değerlendirildiğinde de eğitim kurumları bina, öğretmen ve maddi imkânlar bakımından yetersiz, donanımsız bir durumdadır (Antel,1939). 1924 yılında Türkiye'deki nüfus 12 milyondur. 1920 yılında altı yaşından büyük nüfusun okuma yazma oranı \%10'u bile bulmamaktadır. 1927 yılında yapılan nüfus sayımındaki sonuçlara göre, nüfusun ancak \%11'i okur-yazar durumundadır (Zürcher, 
2006). Cumhuriyet'in ilk yıllarında okur-yazar nüfusun düşüklüğü ve öğretmenlerin mesleki açıdan yeterlilikleri de problemlidir. Eğitim-öğretim müfredatı da çağdaş olmaktan uzaktır (Kanad,1941).

Atatürk, yeniden kurulmakta olan dünyada uzun planlar gerektiren varoluş mücadelesinin eğitilmiş insan gücüyle, ekonomik, bilimsel ve kültürel ilerleme ile kazanılacağını biliyordu. Eğitimin hedefi, medeni milletlerin düzeyini yakalamaktı. Bu hedefe giden yol ise bilim ve fen eğitiminden geçmekteydi. Eğitimin tabana yayıldığı, parasız ve karma eğitimin halkın yararına olarak yaygınlaşması için çabalayan tek başöğretmen de kendisi olmuştur ( Akarsu, 2000).

Aslan (2014), Cumhuriyet Dönemi'nde eğitim politikaları ve pedagojik yaklaşımlara yön veren eğitimcileri şöyle saymaktadır: "İsmail Hakkı Baltacıoğlu, Faik Reşit Unat, Mahmut Cevat, Ziya Gökalp, Sadrettin Celal Antel, Osman Ergin, Halil Fikret Kanad, İhsan Sungu, M. Emin Erişirgil, Nafi Atuf, Rüştü Uzal, İ. Alaettin Gövsa, Selim Sırrı Tarcan, Mustafa Rahmi Balaban, İsmail Hakkı Tonguç, H. Raşit Öymen, Fuat Gündüzalp, Nizamettin Kırşan, Hayri Ardıç, Fuat Baymur, Malik Aksel, Hayrullah Örs, Şinasi Barutçu, İ. Hakkı Uludă̆g, M. Rauf İnan, Kemal Kaya, Muvaffak Uyanık".

Bu eğitimcilerin çalışmaları, temelde eğitimde yapılması gereken yenileşmelere ışık tutmaları ve eksikliklerin giderilmesinde önemli bir yol gösterici olmalarıdır. Cumhuriyet Dönemi'nde "Yokluklar içinde insanımızı nasıl eğitebiliriz?" sorusu öne çıkmıştır. Bu araştırmada, cumhuriyetin kuruluşundan 1960 yılına kadar bir süreç içinde yapılan reformist hareketleri, yabancı ülkelere öğrenci gönderimi, yabancı uzmanların Türkiye'ye gelişleri ve eğitim sistemi hakkındaki raporları tarihsel bir perspektifte incelenmiştir. Araştırmanın alt amaçları şunlardır:

\section{Cumhuriyet Dönemi'nde:}

1. Eğitimde izlenen yeni politika ve planlamalar nasıldır?

2. Hangi alanlarda yenileşme hareketlerine önem verilmiştir?

3. Dönemin politikaları ve eğitim mevzuatı çalışmaları nası yürütülmüştür?

4. Yurt dışı kaynaklı eğitim politika ve planlar nelerdir?

5. Yurt dışına gönderilen öğrencilerden beklentiler nelerdir?

6. Yurt dışından getirilen uzmanların eğitim hakkındaki raporlarında dikkat çeken hususlar ve sorunlara getirdikleri önerileri nelerdir?

\section{Yöntem}

$\mathrm{Bu}$ araştırma, betimsel desende doküman analizine dayanan nitel bir çalışmadır. Nitel araştırmalarda; gözlem, görüşme ve doküman analizi gibi nitel veri toplama yöntemleri kullanılmaktadır. Bu araştırmalarda olaylar, durumlar, deneyimler veya kavramlar birer araştırma konusu kabul edilerek içerik ve doküman analizi yapılmıştır (Yıldırım ve Şimşek, 2016). Bu çalışmada Cumhuriyet Dönemi'nde eğitim alanında gerçekleştirilen eğitim hareketleri, doküman analizine dayanarak sistemli ve bütüncül bir biçimde incelenmiştir. 


\section{Yeni Politika ve Planlar}

Bu bölümde Cumhuriyet ile birlikte yeni dönem eğitim arayışları, Türk ve yabancı eğitimcilerin eğitim sistemi hakkındaki görüşleri yer almıştır.

\section{Yeni Dönemin Eğitim Arayışları}

Cumhuriyetin ilk döneminde eğitim, bir çağdaşlaşma ve sosyalleşme aracı olarak görülmüştür. Bu döneme damgasını vuran Atatürk'ün düşündüğü eğitim; yeni nesillerin Türkiye'yi koruyacak, Cumhuriyeti yükseltecek şekilde yetişmesini sağlayan, millî ve bilim esaslı, üretici, laik ve başarılı insanlar yetiştirmeyi hedefleyen bir eğitimdir (Akyüz, 2010). Bunun için Atatürk, kurduğu yeni Türk Devleti'nin eğitim politikasının dayandığ 1 çağdaş, temel ilkeleri belirlemiş ve bu ilkelere dayalı reformları ve düzenlemeleri kendisi yönetmiştir (Taşdemirci, 2010). Bu dönemde eğitimin, yeni bir toplum yapısı oluşturmanın temel aracı olduğuna inanılmıştır. Cumhuriyet'le birlikte Batı medeniyetine ulaşma konusunda ortaya konulan hedefler, eğitimdeki dönüşüm hareketlerini artırmıştır.

Atatürk, maarifimizin temel amacını "cehaletin giderilmesi" olarak belirlemiştir. Ayrıca başka bir konuşmasında "Gençlere vereceğimiz tahsilin sınırn ne olursa olsun her şeyden önce şunu öğreteceğiz: Birincisi, milletine; ikincisi, Türkiye Devleti'ne; üçüncüsü, TBMM ve hükümetine düşmanlık edenlerle savaşmanın lüzumu"na vurgu yapmıştır (Mütercimler, 2016). Yeni Türkiye Cumhuriyeti'nin eğitimdeki temel amacı; öncelikle ilköğretim ve temel eğitimin vatandaşlara kazandırılması ve Batı medeniyetini ileriye taşıyan değerlere sahip yeni bir toplum yaratılmak istenmesidir. Cumhuriyetin ilk döneminde ulusal bir ortak kültür birliğinin sağlanması, vatandaşlık bilincinin oluşturulması, eğitilmiş nitelikli insan gücünün yetiştirilmesi eğitim politikalarının temelini oluşturmuştur (Gökçe, 2009).

Güler'in (2004), millîleştirme devri olarak sinıflandırdığ1 dönemde (1923-1938) Atatürk'ün ve yeni Türkiye Cumhuriyeti'nin eğitim programının esasları şu şekilde belirlenmiştir:

"Millî karakter motifi, millîlik ilkesi, bilim ve teknik motifi, modernleşme ilkesi, ekonomi motifi, birlik ilkesi, cahilliği yok etme ilkesi, bilimsellik ilkesi, işe dayalı eğitim ilkesi, disiplin ilkesi, laikleştirme ilkesi, karma eğitim ilkesi".

$\mathrm{Bu}$ ilkeler, yeni Türkiye Cumhuriyeti'nin eğitimde hedeflenen doğrultuda geliştirilmesi gereken insan yapısını çizmesi bakımından önemliydi. Eğitim konusundaki büyük çabanın, temel anlamda yeni bir insan tipi ve bireyi yetiştirme paradigmasını da içerdiğini söyleyen Çelebi ve Asan (2013), bu paradigmanın dönemin mevzuat, eğitim uygulamaları, eğitim ile ilgili yayınlar, eğitimciler, entelektüeller ve dönemin siyasetçilerinin konuşma ve uygulamaları ile de desteklendiğini belirtmişlerdir. Tekeli ve İlkin (2014)'de aydınların Cumhuriyet dönemi eğitimi; "köktenci modernleşmenin temel aracı olarak gördüklerini" ifade etmektedirler.

Hesapçıŏlu (2009)'da "Fikri ve irfanı hür kuşakların yetiştirilmesi hedefinin uygulanamadı̆̆ını, 1920'li yıllarda ilköğretimde etkisi geçici olan "yeni eğitim" pragmatizm felsefesinin dışında Türk 
eğitim sisteminin tüm Cumhuriyet tarihi boyunca fikri kökenleri Durkheim'e dayanan bir eğitim sistemi olduğu" tespitini yaparken; ülkemizin zor şartlar altında kurulmasının bireyden çok toplumu önemli kılmasının eğitim felsefesini etkilediği değerlendirmesini yapmaktadır.

Altın (1964), çağdaş eğitim konusunda yenilikçi ve modern eleştirel tutum geliştirilmesini, mevcut eğitim sisteminin değişmesi gerektiğini ve eğitimde değişmenin gerekçelerini ise şu şekilde açıklamaktadır:

- Eğitim, bireyin bir yeteneğini değil, tüm kişiliğinin geliştirilmesidir.

- Kişilikler, sadece hakiki ortamda ve gerçek çalışmalar yoluyla gelişirler.

- Gerçek çalışmaya dayalı üretici bir eğitime geçmeli, suni el işlerine dayalı eğitim terk edilmelidir.

- Okullar, birer sosyal kurum olarak demokratik bir yapıya kavuşturulmalıdır.

Görüldüğü gibi; eğitimde yapılacak yenileşmenin kişinin yeteneklerini geliştirici, üretici ve yaratıcı olmasını, okulların demokratik esaslara uygun kurumlar olarak işlevini sürdürmesi gerektiği vurgulanmıştır.

Cumhuriyetin eğitim politikaları, temelde üç temel hedefe yönelmiştir. Bu hedefler;

- "Kültür birliğinin sağlanması

- Vatandaşlık eğitiminin ve ilköğretimin yaygınlaştırılması

- Türkiye'nin ihtiyaç duyduğu eğitilmiş insan gücünün yetiştirilmesi"dir (Budak, 2003).

Bu idealleri gerçekleştirmek için çoğu bilim dalının ülkemizde olmaması nedeniyle öğrenciler, yurtdışında eğitime gönderilmiştir. Ayrıca, okuma yazma oranlarının hızla artırılması amacıyla örgün ve yaygın eğitime ağırlık verilmiştir. Halk eğitimi için Millet Mektepleri ve Halk Evleri'nin açılması gibi yaygın eğitim faaliyetleri büyük önem kazanmıştır.1923 Hükümet programinda da Atatürk'ün isteği üzerine özellikle bilim, sanat, teknik ve siyaset alanlarında yetiştirilmek için sınavla seçilen yetenekli öğrencilerin özellikle Avrupa ülkelerine gönderilmesi konusu yer almaktadır (Şarman, 2021). Bu durum, Türkiye'nin nitelikli ve üretken insan gücünün yetiştirilmesine yönelik ihtiyacın bir an önce karşılanmasını gerekli kıldığ1 için yurt dışı kaynaklı eğitim bir çözüm olmuştur. Ortaya konulan hedefler, pragmatist eğitim felsefesinin eğitim anlayışını yansıtmaktadır. Türkiye'de açık olan iş sahalarının o alanda seçilen yetenekli öğrencilerin bir an önce yetiştirilerek değişik alanlarda istihdamın sağlanmasına çalışılmıştır.

\section{Dönemin Eğitim Mevzuatı}

$\mathrm{Bu}$ dönemde, ulusal eğitim iki sorunla karşı karşıyaydı: İlki, eğitim-öğretimde hedefin ne olacağı, ikincisi ise belirlenen bu amaç ve hedeflere nasıl ulaşılacağ Bakanı İsmail Safa (Özler) tarafından yayımlanan, sonradan "Misak-1 Maarif" olarak adlandırılan belge ile Türk Eğitim Sistemi'nin temeli atılmıştır, denebilir. Bu belgede eğitimin amacı olarak:

- “Yeni nesilleri geleceğin ihtiyaçlarına göre hazırlamak

- Gençleri fikren kuvvetli, ilim ve ahlaken sarsılmaz karakter haline getirmek 
- Cahilliğin ortadan kaldırılmasını, eğitimin ve okulun yurdun en uzak köşelerine kadar gitmesini să̆lamak

- Gençliği üretmek ve çalışmak fikri ile hayata hazırlamak

- Zayıflık, tüm kötülüklerin anasıdır. Bu nedenle bedenen sağlam, sorumluluk alabilen, kendine güveni yüksek ve haklarına sahip çıkan yurttaşlar yetiştirmek

- Orta dereceli okullardan çıkanların hayata atılmalarını sağlamak" tır (Akgün ve Uluğtekin, 1989).

$\mathrm{Bu}$ hedefleri gerçekleştirecek eğitim kadrolarının oluşturulması ve kararlılıkla uygulanması için cumhuriyete bağlllık önemli bir unsur olarak görülmektedir. Cumhuriyetin Osmanlı İmparatorluğu'ndan devraldığı milli unsurlardan yoksun, birlikten uzak ve çağın gerisinde kalmış eğitim sistemini değiştirmeyi amaç edinen Mustafa Kemal, öğretim birliğinin gerekliliğini 1921 yllında toplanan Maarif Kongresinde "eski devrin hurafelerinden, yabancı fikirlerden, doğudan ve batıdan gelen tüm etkilerden tamamen uzak milli karakter ve tarihimizle uyumlu bir kültür ile sağlanabileceğini" belirtmiştir (Taşdemirci, 2010).

3 Mart 1924' de çıkarılan Tevhid-i Tedrisat Kanunu ile yeni Cumhuriyetin ulusal eğitimdeki temel hedefleri ortaya konulmuştur. Bu kanunla 1924'e kadar vakıflara bağlı olarak faaliyet gösteren eğitim ve öğretim kurumlarının tamamı devletin kontrolü altına alınmış ve Maarif Vekâletine bağlanmıştır. Bu suretle öğretimde birlik sağlanmaya çalışılmıştır. Osmanlı'dan devralınan geleneksel eğitim kurumları kaldırılarak yerine metot ve programları laiklik temeline dayanan Avrupai anlamda okullar açılmış, eğitim- öğretim faaliyetleri çağdaş bir zemine oturtulmaya çalışılmıştır (Akyüz, 2010; Arı, 2002).

Emin Erişirgil ve Avni Başman'ın hazırladığı 1926 tarihli İlköğretim Programı'nda “yeni eğitim" olarak tanıtılan pragmatizm esaslı programa rağmen, orta ve yükseköğretimde Fransız etkisi devam etmiştir. Önce ilköğretim okullarının programlarında, sonra ortaokul programlarında "yeni eğitim" düşüncesi etkisini göstermiştir. Bu eğitimciler J. Dewey'in düşüncelerini uygulamaya çalışmışlardır. Yani Cumhuriyet'in ilanına kadar ve cumhuriyetin ilk yıllarında Fransız, sonra Amerikan ve sonrasında Alman eğitim düşüncesi 1933'ten itibaren yeni gelen Alman profesörlerinin etkisiyle kendini göstermiş ve sonunda 1940 yılında bir kez daha Fransız eğitim sistemine geçilmiştir (Ülken, 2014). 1923'ten 1938 yılına kadar Bakanlık genelgelerinde "Cumhuriyeti sevme, tanıma ve Cumhuriyet'e bağlı kalma gibi " hedeflerin öğrencilere verilmesi gerektiği bildirilmiştir. Örneğin; Mayıs 1927'de Bakan Mustafa Necati Bey'in yayınladığı genelgede: "Cumhuriyeti sevdirmeye ve onun kuruluşunu anlatmaya önem verilmesi ve bunun için her firsattan yararlanılması gerektiğ $i$ " vurgulanmştır (Binbaşığlu, 1995).

Atatürk Dönemi'nde ilkokul müfredatının 1926 ve 1936'da iki kez değiştiği görülmektedir. İlkokulun amaçlarını incelediğimizde; 1926 yılındaki programda "Gençleri yaşadıkları topluma ve değerlerine alıştırarak iyi vatandaşlar yetiştirmek" (Bedri Edis,1933; Antel, 2015), 1936 programinda ise "ulusal terbiye " üzerinde kapsamlı olarak durulmuştur. Ayrıca 1936'da getirilen yeni programın "yurt, iş, topluluk, kendi kendine faaliyet" gibi terbiye esaslarına uygun hazırlandığı belirtilmektedir.

13/12/1931 tarihli Maarif Vekâleti genelgesini İlk Tedrisat Düsturu (1934) adlı eserinden aktaran A. Bedri Edis; o zamanki eğitimimizin temel amaçlarını söyle sıralamaktadır: 
'Türk mektebi, her Türk çocuğunu Cumhuriyet idaresinin psikoloji ve ideolojisini tamamı ile kavramış, Türk Milleti ve Türkiye Cumhuriyeti için azami derecede faydalı bir Türk vatandaşı haline getirmeye mecburdur (md-1)"

'Fikri, ahlaki ve milli terbiyenin gelişimlerine çalışılması, Türk gencinde geliştirilecek kuvvetli muhakeme ve kanaat sayesinde olumsuz tesir ve telkinlere şiddetle karşı koyacak kudret ve kabiliyet kazandırılmalıdır (md-2).

"Mekteplerimiz öğrenciye verecekleri milli terbiye sayesinde tarihi seciyemizle uyumlu bir kültürü kendilerine aşılamak mecburiyetindedirler. Mektepte vereceğimiz edebi, bedii, içtimai ve iktisadi her terbiyenin odak noktası milli terbiyedir (md-3).

"Derslerde teoriye olduğu kadar uygulamaya da önem verilmesi lüzumludur (md-6). Ayrica;

"Genç neslin mektebe ilk girdiği günden itibaren içtimai kudret ve kabiliyetçe müterakki bir inkişafla yetişerek Milli Cemiyet'e ve Türk Cumhuriyeti'ne ruhen ve bedenen en faydalı bir tarzda intibak etmeye azami ehliyet kazanmaları" olarak ifade edilmiştir. 1973 yılında çıkarılan Temel Eğitim Kanunu'nda belirtilen genel amaçların temeli bu yıllarda atılmıştır.

Cumhuriyet idaresinin müfredata koyduğu dersler ise şu şekildedir: Türkçe, Hayat Bilgisi, Jimnastik, Tarih, Coğrafya, Tabiat, Yurt Bilgisi, Eşya, Musiki, Resim-Elişi. Köy Okulları için ise dört dersin üzerinde durulmuştur: “ Okuma-Yazma, Hesap, Yurt ve Hayat Bilgisi ve Ziraat dersleri” (Budak ve Budak, 2014; Cicioğlu, 1985).

Eğitimin yaygınlaştırılması ve niteliğinin artırılması sürecinde kırsal kesime yönelik öğretmen yetiştirme uygulamalarında 1936 yılında "Köy Eğitmeni Projesi" başlatılmıştır. Bu proje kapsamında, askerliğini onbaşı veya çavuş olarak yapan gençler, Ziraat Bakanlı̆̆g'nın işbirliğiyle, modern tarım tekniklerini uygulayacak biçimde yetiştirilerek halk ile kentliler arasındaki bozuk dengeyi eşitlemek ve köy halkına pratik bilgi vermek amacıyla köylere gönderilmiştir. Bu uygulama, daha sonra kurulan Köy Enstitüleri'ne geçişi kolaylaştırmıştır. 1937 ve 1939 yıllarında çıkarılan yasalarla köy eğitmeni yetiştirme deneyimi yaygınlaştırılmıştır. 1940 yılında açlan Köy Enstitüleri 1954'e kadar işlevini sürdürebilmiştir. Köye gönderilen köy öğretmenlerinin, “okulda öğrencilere eğitim vermesinin yanı sıra alternatif ve yeni tarım tekniklerini köylülere öğretmek, okuma yazma kursları düzenlemek, bahçe ve tarla gibi tarım arazileri açmak, imece usulüyle yol yapımını sağlamak" gibi görevleri de vardı (Akdemir, 2013; Çelebi ve Asan 2016; Çetin ve Gülseren, 2003).

\section{Dönemin Eserlerinde Yeni Eğitim Arayışı ve Anlayışlar}

Cumhuriyet yönetimi, eğitim işlerine "yeni insan tipi yaratmak" gerektiği inancı ile bakmaktaydı. Bu insanı yaratmak için eğitim politika ve ilkelerini iyi belirlemek gerekiyordu (Nami, 1934). Dönemin pedagoji profesörlerinden Sadrettin Celal Antel de "Maarifimiz ve Meseleleri" adlı eserde "Mekteplerimizin talimat ve programlarında büyük yenilikler yapılmış ve bu suretle, imparatorluğun milli ve asri olmayan maarifinin yerine, bütün manası ile milli ve modern bir maarif sistemi kurulmuştur'" yorumunu yapmaktadır (Antel,1939).

Eğitim konusunda yenilikçi ve modern eleştirel tutum geliştiren İsmail Hakkı Baltacıoğlu, öğretmen yetiştirme konusunda köy enstitüleri konusunda; " Dikkat edilmesi gereken husus öğretmen adayını her açıdan eksiksiz yetiştirmektir. Çünkü en iyi öğretmen mükemmel olan değil, eksiği 
en az olan öğretmendir. Öğretmenlerin alan bilgisi yanında tabii ilimleri bilmesi, o aynı zamanda bir bahçıvan, hasta bakıcı veya bir aşçı olabilmelidir" görüşünü ileri sürmüş, eğitimin bir bilim olarak beş eğitim ilkesi üzerinde durmuştur. Bu ilkeler: Kişilik ilkesi, çevre ilkesi, çalışma ilkesi, verim ilkesi ve başlatma ilkesidir (Aytaç, 1979; Sönmez,1996).

Yine dönemin Gazi Terbiye Enstitüsü öğretmenlerinden Halil Fikret Kanad, "Pedagoji" adlı eserinde Cumhuriyet Dönemi'nde pedagojik anlayışı; "Çocukları iyi anlamak; zamanında tesirli müdahalelerde bulunmak" olarak tanımlamış ve öğretmenliği " bilgi işi olmaktan ziyade seziş ve sanat işi" olarak gördüğünü belirtmiştir (Kanad,1941). Dönemin diğer bir eğitimcisi Nafi Atuf Kansu ise "Pedagoji Tarihi" adlı eserinde "Terbiyeden maksat, diğger insanlara bir şey öğretmek, onları ıslah etmek için bir adamın iradesi ile vücuda getirdiği tesirdir" diyerek eğitimden beklentisini yansitmıştır (Kansu,1929).

Angelo Patri'nin, "Yarınki Mektebe Doğru" adlı kitabının önsözünde o dönemin öğretmenlerinden biri olan Kazım Nami'nin "Yarınki demokrat Türkiye'yi kuracak bu çocukları pekiyi bilirsiniz ki öğretmenlerin eline milletçe, devletçe, ailece emanet edilmişlerdir. Yarnki Türkiye'yi kuracak olan çocuklara biz "Şöyle yapınız, böyle yapınız" demeyeceğiz. Bizler böyle emirlerle büyüdük, kendi benliğimizi kendiliğimizden inkişaf ettiremedik; onun için bugünün adamı olmakta güçlük çekiyoruz. Biz çocuklarımıza hürmet edeceğiz, ne olacaklarsa kendileri olacaklar, ne yapacaklarsa kendileri yapacaklar" demesi o dönem için ilerici pedagojik yaklaşımı göstermesi ve cumhuriyetin hedefi olan insan modelini tanımlaması bakımından güzel bir örnektir (Nami,1934).

Yine Kazım Nami (1934), kendi yazdığı “Muallimin Meslek Ahlakı" kitabında "Okulun, çocuğun kendi gelişimi için çalışırken, diğer yandan ona toplumsal ve siyasi görevlerini de öğrettiğini, çocuğa hürmet edilmesini, kabiliyetlerini tespit edip değerlendirmek gerektiğini ve çocuğu fazilete doğru yürütmek amacı olduğunu" belirtmektedir

Dönemin eğitimcilerinden İbrahim Alaaddin Gövsa "Çocuk Ruhu" adlı eserinde (1929)"'Muallimin ilk vazifesi çocuğu ve kabiliyetlerini tanımaktır" demektedir.

D.M Geraskof'un yazdığı " Talim ve Terbiyede Kendi Kendine Faaliyet " adlı kitabın önsözünde Gazi Terbiye Enstitüsü öğretmenlerinden Hasip Ahmet ise "şahsen faal eğitim ve öğretim taraftarı olduğunu, faaliyet prensibi fikrinin okullarda, öğrencinin kendi kendine eğitim ve öğretim faaliyeti şeklinde, fakat mümkün ve normal sınırlar içinde kullanılmasını arzu ettiğini" söylemektedir (Geraskof, 1933).

Eğitim ve öğretim faaliyetlerinin düzenlenmesine ilişkin ortaya konulan görüşler ve yayınlanan yönetmelik ve genelgeler, yeni program anlayışı çerçevesinde ele alınmış olmasına rağmen yapılan çalışmalar yeterli olamamıştır. 


\section{Yurtdışı Kaynaklı Eğitim Politika ve Planları}

Atatürk döneminde "Batı" eğitim sisteminin esas alınması nedeniyle eğitim ile ilgili yurtdışı kaynakları araştırılmıştır. Yetişmiş insan gücü eksikliği nedeniyle temelde üç yol uygulandığı söylenebilir:

- Yurtdışına eğitim için öğrenci gönderilmesi

- Yabanci uzmanlara inceleme yaptirılması

- Üniversite reformu ve mülteci akademik kadro.

\section{Yurtdışına Eğitim İçin Öğrenci Gönderilmesi}

Cumhuriyet yönetimi, nitelikli ve eğitimli insan gücünün oluşturulması için ülke dişına öğrenci gönderme konusunu ilk kez Tevhid-i Tedrisat Kanunu ile ele almış ve 29 Ekim 1924' te Maarif Vekâleti'nin yurtdışı sınavıyla da yurtdışına öğrenci göndermeye başlamıştır. Sınavı geçen 22 öğrenci Almanya başta olmak üzere, Fransa ve Belçika'da eğitim alma hakkını kazanıp ilgili ülkelere gönderilmiştir (Şarman,2021).

Yurt dışına gidecek öğrencilerin sayısı, gidilecek ülkeler, kaydolacakları bölüm, ödenek, hak ve sorumluluklar gibi konuları belirleyen temelde yasal dayanaklar mevcuttur. 1924 ve 1927 yılında çıkarılan Yabancı Ülkelere Gönderilecek Öğrenciye ait Yönetmelik ve 1929 yılında çıkarılan ve değişikliklerle hâlâ uygulamada olan “Ecnebi Memleketlere Gönderilecek Öğrenci Hakkındaki Kanun"(İçke,2015).

Ayas (1948), öğrenim için yurtdışına gidecek öğrencileri üç sınıfta tanımlamıştır:

- Bir okula veya üniversiteye eğitim için gidenler: Devlet, il idareleri, belediyeler, ticaret odaları, öğrenci göndermeye mecbur şirketler tarafından öğrenci seçilmekte, her yıl Nisan ayı sonuna kadar öğrenci sayısı, öğrencinin gideceği ülke, öğretim planı gibi bilgilerin Milli Eğitim Bakanlığı'na sunulması gerekmektedir.

- Memur iken gönderilenler: Beş yıla kadar ( Bakanlıkların izni ile daha da uzatılabilir) aylıkları kesilerek veya kesilmeden devlet memurlarının yurtdışı eğitimine izin verilmiştir.

- Kendi imkânlarıyla kendisi için gidenler: Belli kurallara uyularak kişilerin kendi imkânlarıyla yurtdışına gidişine izin verilmiştir.

1925 yılının başında İstanbul'dan yola çıkan ilk öğrenci grubunda gelecekte başbakanlık da yapacak olan Sadi Irmak ve Hayri Ürgüplü, diğerleri; Mahmut Cüda, Muhittin Sebati, Refik Epikman, Ulvi Cemal Erkin, yine gelecekte üne kavuşacak olan yazar ve şair Necip Fazıl Kısakürek ve diğerleri; Cezmi Rıfık, Cemil Sena Ongun, Naci Ecer, Aşir Savaşır, Burhan Toprak, Zeki Ün, Osman Horasanlı, Cevat Dereli, Şeref Akdik, Münip Karsan, Namdar Rahmin gibi kişilerin olduğu görülmektedir (Özodaşık, 1999).

Cumhuriyet döneminde yurt dışı eğitim sürecinin, kanuni uygulamasının planlı olduğu söylenebilir. Yurt dışına gönderilecek öğrencilerin seçimi için yapılan sınavlar, mevzuat, 
üniversiteyi bitirme planları ve denetimi, ayrılan para ve kaynaklar bu planlı gidişin göstergeleri olarak değerlendirilebilir. Yapılan sınavlarda, yurtdışına öğrenci gönderimi için başvuranlar kadar değil, başarılı bulunan öğrencilerin sayısınca öğrenci gönderilmiştir. Öğrenci başvurusunun yetersiz olması durumunda ise sınavların iptal edilip daha sonraki tarihlerde tekrar edildiği de olmuştur (Aslan, 2014).

Maarif Vekâleti, yurtdışına gönderilecek öğrencileri seçmek maksadıyla "Avrupa Konkuru" adı verilen sınavları düzenlemeye 1924 yılı Ekim ayında başlamıştır. Sınav başarılarına göre seçilen 22 kişilik ilk grup, Almanya ve Fransa'ya gönderilmişlerdir. Yetersiz kaynaklara rağmen bütçeden ödenek ayrılacak devlet hesabına; fen bilimlerinden sosyal bilimlere; güzel sanatlardan arkeolojiye kadar birçok alanda öğrenci yurtdışına gönderilmiştir.1928-1945 yılları arasında yılda ortalama 120 öğrenci gitmiştir (Şarman,2021).

İçke (2015), yaptığı çalışmada, yurt dışına giden öğrencilerin dağılımlarını 1923-1938 yılları arasındaki dönem için şöyle vermektedir:

Tahsil için yurt dışına gönderilen toplam 925 öğrencinin, gönderildikleri ülkeler arasında, \% 37,97 ile Almanya ilk sırada yer alırken, bunu sırasıyla \% 28,93 ile Fransa, \% 8,22 ile Belçika, \% 6,09 ile Amerika, \% 4,47 ile İsviçre, \% 4,16 ile İngiltere, \% 1,52 (ile Avusturya ve İtalya, \% 1,32 ile Macaristan, \% 0,82 ile Çekoslovakya, \% 0,3 ile İsveç ve \% 0,1 (1 kişi) ile Japonya ve Lehistan izlemiştir. Gönderilen öğrencilerin \% 47.92'sini (472 kişi) Maarif Vekâleti göndermiştir. İktisat, Ziraat, Savunma Bakanlığı ayrıca Denizyolları ve Maden Tetkik Arama (MTA) gibi değişik kurumlar da yurt dışına öğrenci göndermiştir. Örneğin; 1937 yılında Türkiye'den yurtdışına devlet bursluyla giden 234 öğrenciden 133'ü Almanya'ya gönderilmiş, Türkiye, 1941 yılına kadar üniversite öğrencilerinin Almanya' daki eğitimlerine destek vermiştir (Ernst Reuter akt. Möckelmann, 2020).

1923 - 1938 arasında öğrencilerin \% 41,52'si Mühendislik ve Uygulamalı Bilimlerde, \% 14,62'si Sosyal Bilimlerde, \% 12,59'u Temel Fen Bilimlerinde, \% 7,92'si İktisadî, İdarî, Hukuk ve Malî Bilimlerde, \% 7,21'i Tarımsal Bilimlerde, \% 6,09'u Güzel Sanatlar, Müzik ve Beden Eğitiminde ve \% 1,32'si Sağlık Bilimlerinde öğrenim için yurt dışına gönderilmiştir. Mühendislik Biliminin çeşitli alanlarında öğrenim için öğrenciler yoğun olarak Almanya'ya gönderilirken, Temel Fen Bilimleri ile Sosyal Bilimlerde öğrenim için öğrenciler daha çok Fransa'ya, Mühendislik ve Uygulamalı Bilimlerin Dökümcülük, Marangozluk, Otomobil Tamirciliği, Moda ve Çiçek, Kadın Terziliği gibi uygulamalı alanlarında öğrenim için öğrenciler ise, daha çok Belçika'ya gönderilmişlerdir (İçke,2015).

Yurtdışında okuyan öğrencilerin büyük kısmı burslu olduğundan kitap masrafları, okul harçları, hastane giderleri gibi harcamalar, Cumhuriyet İdaresi'nce karşılanmıştır. Verilen bursların ve sunulan diğer hizmetlerin gerçekten iyi olduğu rahatllkla söylenebilir. Bir örnek vermek gerekirse;

"Almanya'da yaşayan öğrenciler şahsi harcamaları için ayda 98 lira (300 Alman Markı), Amerika'daki öğrenciler 125 dolar burs almaktadır. Bu miktarlar Türk öğrencilerinin rahat bir yaşam sürmeleri için yeterli olarak değerlendirilmektedir" (Öksüz ve Köksal, 2018).

Yurtdışına gönderilenlerin çoğu maddi durumu iyi olmayan henüz İstanbul'u bile görmemiş gençlerdi. Sınavı kazandıktan sonra aldıkları burs rahat yaşamalarına yetecek düzeyde idi. 
1930'lu yıllarda öğrencilere burs olarak verilen yaklaşık 100 liralık aylık, Türk lirasının değerinin ve alım gücünün yüksek olması, özellikle gittikleri ülkelerdeki bozuk ekonomik yapı ile birleştiğinde ellerine geçen para miktarının artması sonucunu doğurmuş ve onlara rahat bir yaşam sağlamıştır. Bu durumu ünlü arkeolog Ekrem Akurgal'ın anılarını aktaran (Başgelen, 2011) şöyle dile getirmektedir:

“....Bir aralık bir Türk lirasına, 6.5 Registermark alırdık. Öğrenci bursumuz 96 lira idi, yani ayda 650 mark gelirimiz vard. Bu para o dönemde bize bol bol yetiyordu. Alman öğrenciler ayda 150 markla geçinirlerdi. Bazen Kempinski, Mampe gibi ünlü restoranlara giderdim. İyi giyinirdim. İyi tanınmış ailelerin evlerine davet edilirdim. Berlin'in hep en güzel semtlerinde oturdum..."

Cumhuriyet, yurtdışındaki burslu öğrencilerin denetimi için görevlendirdiği müfettişleri; parasal konularla, öğrencilerin genel durumlarıyla ilgili raporlar hazırlamakla yükümlü tutmuştur. Müfettişler, öğrencileri izlemek için sık sık seyahat etmişlerdir. Öğrencinin mezuniyetinin uzaması halinde müfettişin hükümete durumu bildiren bir rapor gönderip öğrencinin devlet tarafından burslu olarak okutulmasının iptalini önerme yetkisi vardır. Her bir öğrencinin yurtdışında eğitimi için ortalama 10.000 lira harcanmaktadır. Doktora için yurtdışına giden öğrencilere ortalama 7 yıl süre tanınmaktadır (Öksüz ve Köksal, 2018). Yine yurtdışına burslu olarak gönderilen öğrencilerin denetiminin sıkı şekilde takip edildiğini ve denetim için ilgili ülkelerdeki büyükelçilerin de görevlendirildiklerini; Başbakan, Dışişleri Bakanı ve Genel Sekreter'le ilk konuşmalarının konusunun öğrenimde olan öğrencilerle ilgili olduğunu, Türkiye'nin İran, Japonya ve Almanya büyükelçiliklerini yapmış olan Hüsrev Gerede (2020), anılarında belirtmektedir. Aynı eserden bir örnek verecek olursak Gerede, Berlin Büyükelçiliği döneminde eğitimin izlenmesi için yapılanları şöyle sıralamaktadır:

- “ Almanya'da eğitim alan gençlerin durumunu yakından izlediğini, gençlerin iyi yetişmeleri ve milli onurumuzu korumaların sağlamak için birebir görüşmeler yaptığını,

- Öğrenimlerine devam edemeyecekleri anlaşılan ve Almanya'da ikamet etmeleri uygun görülmeyen birkaç öğrencinin denetimler sonucu Türkiye'ye geri gönderildiğini,

- Berlin'de kiralanan binanın bir kısmının gençlerimizin oturma ve okuma alanı olarak ayrıldığını, Berlin ve Dresden şehirlerinde iki öğrenci cemiyeti kurulduğunu,

- Kültür merkezlerinde ve toplu olarak öğrenim görmelerine önem verildiğini,

- Öğrencilerin bulundukları ülkenin öğrencileriyle aynı seviyede olmaları, onları arasına karışabilmeleri, arkadaşlık edebilmeleri, kulüplerine gidebilmeleri, birlikte spor yapmalarının önemsendiği, onların yaşam tarzların öğrenebilmeleri ve yabancı dillerinin kuvvetlenmesinin önemli görülldü̆̆̈̈nü" belirtmektedir (Gerede, 2020).

Yurtdışına eğitim için gönderilip, ülkesine dönenler memlekete büyük hizmetlerde bulunmuşlardır. Bakanlık hatta Başbakanlık yapanlar da olmuştur. Örneğin; Haşim Şensoy, ilk elektrik, Adnan Erkmenol, ilk endüstri, Bahri Ersöz, ilk metalürji, Hamit Geriş, ilk makine, Adnan Şener, ilk kimya, Aziz Tanrısever ise ilk ziraat mühendislerindendir. Oktay Aslanapa ilk sanat tarihçisi, Cevdet Arun, ilk beden eğitimi öğretmenidir. Mehmet Ali Kâğıtçı, kâğıt üretimi için Almanya'ya eğitime gitmiş, dönüşünde kâğıt fabrikalarının kuruluşunda görev almıştır. Şevket Ratip Hatipoğlu ise ziraat ve felsefe eğitimi alıp Tarım ve Milli Eğitim 
Bakanlığ1 yapmıştır. Sadi Irmak ise doktorluk eğitimi alıp ordinaryüs profesör olmuş sonrasında Başbakanlık yapmıştır (Tekeli ve İlkin, 2014).

\section{Yabancı Uzmanların Türk Eğitim Sistemine İlişkin Görüşleri}

Atatürk'ün Maarif Kongresi'nde söylediği gibi "yenilik yaratan çözümler" üretilmeliydi. Fransa ve Almanya'da eğitim almış olan Cevat Dursunoğlu, Rüştü Uzel, Selim Sırrı Tarcan, İhsan Sungu, C. Atuf Kansu, İsmail Hakkı Tonguç, İsmail Hakkı Baltacığlu, Halil Fikret Kanad ve Raşit Öymen gibi çekirdek kadro bu çözümlere ön ayak olmuştur (Aslan, 2014).

Bu gelişime paralel olarak erken Cumhuriyet döneminde Türkiye'ye az sayıda ABD'li eğitim uzmanının yanında Almanya, Avusturya, Belçika, Çekoslovakya Fransa, İngiltere, İsveç, İsviçre, Macaristan, Rusya ve Yugoslavya'dan eğitim uzmanları davet edilmiştir. İlk yıllarda gelen eğitim uzmanları genellikle Avrupalı uzmanlar iken, 1950'den sonra gelen uzmanların neredeyse tamamı Amerikalıdır (Şahin, 2016). 1923-1950 yılları arası 79, 1950-1960 arası 44 olmak üzere 123 eğitimci yabancı uzman yurtdısından Türkiye'ye davet edilmiştir. Bu eğitimciler, Türk eğitim sistemini incelemişlerdir. John Dewey, Alfred Kühne, Omer Buyse, Albret Malche, Beryl Parker, ve Kate V. Wofford raporlarında, Türk eğitim sistemindeki sorunları; ezberlemeye dayalı eğitim, nitelikli öğretmen yetiştirememe, etkin denetim eksikliği ve öğrenciler arası işbirliği eksikliği olarak sıralamışlar ve yeni eğitim sistemindeki düşünce ve uygulamalar hakkında görüşlerini bildirerek çözüm önerileri sunmuşlardır (İlkin ve Tekeli, 2014; Kartal, 2016; Yalçın, 2019). Eğitimde Kerschensteiner'ın “çocuğa kendisinin bulabileceği hiçbir şeyi söylememe" ilkesi ve eğitim sisteminin merkezileşmesinin gerekliliğine inanç, bu dönemde önemli bir görüştü. Bu dönemin, eğitimde ne gibi yenilikler yapılabileceği konusunda tam bir arayış dönemi olduğu söylenebilir.

1932 yılında üniversite reformu için Almanya'dan tarımla ilgili öneriler hazırlayan bir heyet, 1933 yılında da Kemmerer'in yönetimindeki Amerikan komisyonu, ekonomi hususunda tespitler yapıp öneriler sunmak için ülkemize gelmiştir. Raporda eğitimle ilgili tespit ve önerilerin de bulunduğu önemli bir bölüm de vardır. Amerikan Heyeti Raporu'nun (1939) bizim için en önemli özelliği, eğitimin ülkenin ekonomik yapısıyla uyumlu bir şekle getirilmesi için neler yapılması gerektiğidir. Raporda, eğitimin genel durumu, istatistiksel bilgiler, 1932' deki mevcut durum, ilköğretim, ortaöğretim, öğretmenler ve öğretmen yetiştiren kurumlar, yükseköğretim, yurtdışına öğrenci gönderilmesi, sanat mektepleri, ticaret mektepleri, halk eğitimi gibi diğer sorunlar ele alınmıştır. Öğretmen yetiştirilmesi hususunda belirli adımların atıldığını ifade eden Hines-Kemmerer, artık nicelikten ziyade niteliğin önemsenmesini önermiştir. Grup, bu konuda öğretmenin moralini yüksek tutmak için çözüm önerilerinde bulunmuştur: Heyetin raporunda dikkati çeken bir diğer konu ise; "köye gönderilecek öğretmenin köy koşullarına uyum sağlayabilmesi, köy ve köylü ile özdeşleşebilmeleri için bir köy öğretmenliği modelinin oluşturulmasının gereği" olduğunun vurgulanmasıdır (Marım ve Sam, 2018; Şahin, 2016).

1923-1938 yıllarında, G. Oldenburg ve Falke'nin tarım eğitimi, E. Arnold Egli ve C. Holzmeister'in okul mimarisi, G. Stiehler ve O. Frey'in ise sanat eğitimi konusunda incelemeler yapmak üzere ülkemize geldiklerini görüyoruz. Yabancı uzmanların verdikleri 
raporlar, Türk eğitim sistemi üzerinde önemli etkiler yaratmıştır. Önemli tavsiyeler barındıran 1927 yılında teknik okulların durum tespiti ve ileriye dönük geliştirme önerileri için gelen O. Buyse'in meslek eğitimi ile ilgili raporu uygulama bulamamıştır. 1925' de A. Kühne'nin meslek eğitimi, B. Parker'ın ilkokul eğitimi ile ilgili raporları ve Amerikan Heyeti Raporu'nun eğitim ile ilgili önerileri de fazla etkili olamamıştır. 1924 yılında A.B.D'li eğitim uzmanı ve felsefecisi John Dewey, eğitimimiz için genel değerlendirme ve öneriler için gelmiştir. Genel olarak değerlendirildiğinde, ülkemize yurtdışından gelen öğretmen ve uzmanların Türk eğitiminin gelişimi ve ilerlemesine önemli katkıları olduğu söylenebilir (Ortak, 2004). Eğitim üzerine en kapsamlı ve genel raporu J. Dewey yazmıştır. Bu sebeple raporunda üzerinde durduğu konular önemlidir. Dewey'in raporundan dönemin eğitim anlayışı ve istenen eğitim için gerekenler özetle şu şekilde yer almıştır:

“Türk eğitim sisteminde kısa zamanda yapılacak yüzeysel reformlardan daha fazla, ileriki zaman dilimine yayılmış gelişim plan ve müfredatına ihtiyaç bulunmaktadır. Eğitimde modernleşme ve ilerlemeyi sağlayabilecek eğitim uzmanlarının yetiştirilmesi gerekmektedir. Eğitim Bakanlığınca, eğitimle ilgili çalışma, plan ve müfredatı inceleyecek, planları hazırlayacak kurullar oluşturulmalıdır. Böyle kurullar kurulursa Ĕ̆gitim Bakanlığı bürokratik işlemlerle uğraşmaktan kurtulur. Türkiye dışında eğitimle ilgili yayınlanan yapıtlar Türkçeye çevrilerek yayımlanmalıdır. Çeviriler, öğretmenlerin en fazla ihtiyaç duyduğu alanlardaki kitaplardan oluşmalıdır. Okul binalarının tasarım ve mimarisi, öğrencilerin pratik yapma ve keşfetme yeteneklerini geliştirecek şekilde olmal, binalarda temizlik kurallarına uyulmal, binaların araç-gereç ihtiyacı sağlanmalıdır. Okullarda, ders sırasında öğrencinin kullanımı için ders aletlerinin sayısı arttırılmalıdır. Yeni meslek edindirme okullarını açmak yerine, eldeki okullar iyileştirilmelidir. Okullar. sadece ders yapılan yerler değil, toplumsal yaşamın merkezi olmal ve toplumsal yaşamda gerekli olacak bilgiler öğretilmelidir (Dewey, 1939)".

Dewey'in raporuna da değinilen Amerikan Heyeti Raporu'ndan Maarif İşleri adlı eserde (1939), gelecekte eğitimden istenilen verimin alınabilmesi için dört alana dikkat edilmesi gerektiği vurgulanmıştır. Bunlar; "Tarım, Mühendislik ve Fen, Nitelikli İşçi ve Yönetici Yetiştirilmesi, Ticaret Eğitimi"dir. Sistemin kendi ihtiyaçlarına uygun uzman yetiştirilmesini önermesi eğitimde kültürel değerlerin önemine vurgu yapılması bakımından önemlidir. Buna benzer şekilde eğitimde değişim alanında tanınmış araştırmacılardan Michael Fullan, eğitimde değişimin teknik olarak kolay, ancak toplumsal olarak karmaşık olduğunu ifade etmiştir (Er, 2019: 99-124).

\section{Üniversite Reformu ve "Mülteci " Akademik Kadro}

Türkiye'de yükseköğretimde modernleşme, Atatürk'ün 1933 y1lında gerçekleştirdiği "Üniversite Reformu" ile başlamıştır. Yükseköğretimde gerçekleşen bu modernleşme çabasında, Almanya'dan mülteci olarak Türkiye'ye gelen bilim insanlarının çok büyük katkıları görülmüştür. Darülfünun'un kapanıp İstanbul Üniversitesi'nin açılmasıyla fakültelerde mülteci bilim insanları göreve başlamış ve alanlarındaki çalışmalarıyla öncü ve yol gösterici olmuşlardır. Yabancı uzman ve profesörler, Türkiye'ye gelirken imzaladıkları sözleşmeye göre atandıkları bölümde ders yapma, seminer çalışması yaptırma, öğretim elemanı yetiştirme gibi öğreticilik faaliyeti yanı sıra belirli bir süre içinde Türkçe öğrenmek ve derslerini Türkçe verebilir hale gelmek gibi sorumluluklar da üstlenmişlerdir. Bu dönemde 
üniversitedeki kütüphaneler zenginleştirilmiş, yeni hazırlanan okul kitaplarının içeriği daha uygun hale getirilip, bu kitaplara ulaşmak kolaylaştırılmıştır. Ayrıca bu dönemde bilimsel çalışmalar haricinde birçok asistan ve öğretim üyesi de bu mülteci bilim insanları tarafından yetiştirilmiştir (Çelebi, 2003; Namal, 2012).

İsviçre'de Cenevre Üniversitesi pedagoji profesörü Albert Malche, Türkiye'ye çağırılarak İstanbul Darülfünunu konusunda tespit ve önerilerini içeren bir rapor yazması istenmiştir. Malche, 1932 tarihinde dönemin Maarif Vekili Esat Sagay'a raporunu sunmuştur. Malche, tarafından hazırlanan İstanbul Üniversitesi reorganizasyon ve reform planı uyarınca yabanc1 üniversite hocalarının istihdam edilmesi için Türkiye' nin tek şartının kendi alanlarında "isim sahibi" yetkili kişi olmak olduğunu belirtmektedir. Bu rapor, 95 sayfadan oluşmaktadır ve Millî Eğitim Bakanlığg'nca "İstanbul Üniversitesi Hakkında Rapor" adıyla yayımlanmıştır. Rapor, 5 bölüm ve 49 maddeden oluşmaktadır (Malche, 1939).

1. Bölüm: Üniversitenin amacı, bütçe ve yapılanma konularını,

2. Bölüm: Eğitim kadrosu konusunu,

3. Bölüm: Yönetim kadrosunu,

4. Bölüm: Öğrenci ile ilgili hususları,

5. Bölüm: Üniversite' de yıllık eğitim programını, sınavlar ve dereceler" konularıdır.

Profesör Malche'nin raporundaki bazı önemli tespit ve öneriler şöyledir (Malche, 1939):

- Yeteri kadar Türkçe yayın yoktur, yabancı eserleri okuyabilecek dil bilen öğrenci sayısı azdır. Üniversitenin ilk yılında dil öğretilmelidir.

- Üniversitede görevlendirilen memur sayısı ihtiyaçtan fazladır. Üniversitede ihtiyaç sahibi öğrenciler görevlendirilebilir.

- Üniversiteye devam edip bitiremeyecek öğrencilerin ilk yıldan bırakmasını sağlamak iyi olur.

- Üniversiteyi bilimsel ve düşünsel bilinçli olarak bir hedefe yöneltilmelidir.

- Profesörlerin oyuna başचurulup görüşleri öğrenilmelidir, ancak son karar Maarif Vekâleti'ne ait olmalıdır (En çok eleştirilen konulardan biri profesörlerin atanma şeklidir)

- Üniversitedeki sinavlar çok zor olmal, ezbere dayalı olmaktan çok bilgisini uygulama sahası olan konulara ait olmalıdır. Uygulamalı dersler müfredatın en az üçte birini oluşturmalıdır.

- Profesörlerin kitap yazması için davet ve teşvik edilmesi gereklidir.

- Üniversitede öğrenciler seminer verebilmeli, dersleri kendisi hazırlamalıdır

- Üniversitede öğrenci ödüllendirme sistemi olmalıdır.

- Üniversite kongreler düzenlemeli, bir üniversite dergisi çıkarılmalıdır".

Rapordaki belki de en önemli husus "Başlıca mesele, bilimleri ezberleyerek değil, yaratıcı düşünceyi kullanarak düşünmektir. Üniversitenin bilimsel zihniyeti yaratmak sorumluluğu vardır ve bunun dışında kurtuluş yoktur" tespitidir. Bu tespit ise bugün için bile geçerlidir (Erdem, 2012; Özata, 2007; Taşdemirci, 2010).

Malche'nin raporunu sunmasının ardından 1933 yılında Darülfünun kapatılmıştır. İstanbul Üniversitesi olarak yeniden açlan kurumda öğretim üyelerinin bir bölümü göreve devam edemezken, çeşitli alanlarda yabancı öğretim üyeleri çalışma imkânı bulmuştur (Er, 2019). Namal ve Karakök (2011) yapılan üniversite reformunun getirdiği yenilikleri şöyle özetlemektedir: 
- Bilimsel ve idari özerklik verilmiştir.

- Üniversitedeki kariyer basamaklarının yasal dayanakları belirlenmiştir.

- Üniversitelerin, kendi bütçesiyle yönetilmesine çalışılmıştır.

- Kaynakları artırılmıştır.

- Yeni öğretim elemanı yetişmiştir.

- Eğitim ve araştırma araç-gereç ve donanımları arttırılmıştır.

Reisman (2011) da yaptığı çalışmada, toplamda 300 akademisyen ve 50 teknisyenin geldiğini 190 öğretim üyesi veya görevlisinin Türkiye'de uzun süreli çalıştığını belirtmekte ve hiçbir ülkenin kendi amaç ve hedeflerine ulaşmak için ulusal politika ve planlama geliştirmediğini belirtmektedir. Üniversitede 1933 yılında görevli profesörlerin dağılımı incelendiğinde ise akademik kadrodaki 138 Türk akademisyene karşılık, 42 yabancı uyruklu akademisyen olduğu tespit edilmiştir (Çelebi (2003).

Akyüz'e (2010) göre, üniversitelerde görevlendirilen yabancı profesörler Türk üniversite ve bilim hayatına önemi katkılarda bulunmuşlar ve birçok öğretim üyesinin yetişmesini sağlamışlardır. Birçok enstitü, klinik, laboratuvar, kürsü kurulmasına ön ayak olmuşlardır. Çoğu Türkçe öğrenmiş, ders kitabı yayınlamıştır. Möckelmann (2020) eserinde, Türk akademisyenlerinin, gelen Alman bilim insanlarına verdiği desteğin önemli olduğunu belirtmektedir. 1933'ten sonra üniversitelerin kurulmasında akademisyen, aydın ve seçkin bir sınıfın yetişmesinde, hükümet danışmanlığı ve uzmanı oldukları mesleklerde yaptıkları reformlar konusunda da Almanya'dan gelen bilim insanlarının önemli rolü olduğunu belirtmektedir (Möckelmann, 2020).

Cumhuriyet döneminde Türkiye'ye gelen bilim insanlarından biri, hukukçu Ernst E. Hirsch de "Anılarım" adlı kitabında (2008); 1933 yılında patoloji profesörü Philipp Schwartz'ın başkanlığında "Alman Bilim İnsanları Yardımlaşma Cemiyeti'nin" kurulduğunu, bu cemiyetin Almanya'da tehlikede olan "politik sebeplerle istenmeyen ilan edilen" ve "Yahudi" olan bilim insanlarını Almanya'dan çıkarmaya çalıştığını bildirmektedir. Yine Hirsch (2008); "Kendi Alman vatanından Yahudi olmasından dolayı evini yurdunu terk edip kovulduğunu, ancak dünyanın diğer ucundaki yeni Türkiye Cumhuriyeti'nin ise kendisini Türkiye'nin ilk bin kişilik seçkininden sayıp, saygıdeğer bir mevki ile işe aldığııdan" övgüyle söz etmektedir (Hirsch, 2008).

Yabancı profesörlerle yapılan anlaşmalara değinen Özata, (2007) şartları ve sunulan imkânları şöyle özetlemektedir:

(1)Yabancı profesörler, sadece üniversite ile meşgul olacaklar başka işle uğraşmayacaklar; (2) Eksik olan Türkçe ders kitaplarını kısa zaman zarfında tamamlayacaklar (3) Üniversitede çalıştıkları üçüncü yıldan itibaren derslerini Türkçe olarak yapacaklar; istendiğinde bilirkişi raporu hazırlayacaklar; (4) Toplumsal kalkınma için kurulan tesislerde rol ve görev alacaklardır. Karşılı̆̆ındaysa: (1) Emsalleri olan Türk profesörlerden yüksek maaş alacaklar (Bir Türk profesör 150 lira maaş alırken yabancı profesörlere 500-800 lira arasında değişen maaşlar verilmiştir), diğer masrafları karşılanacak, sağlık sigortasından yararlandırılacaklar; (2) Birlikte çalışmak istedikleri kişileri Türkiye'ye kabul hakkı verilecektir; (3) Kendilerine Türkiye Cumhuriyeti'nin koruması verilecektir. 
Resmi Gazete' de 2397 sayılı kanunla 1934' de yayınlanan, İstanbul Üniversitesi'nde istihdam olunacak yabancı profesörlerle yapılan iş anlaşmasına ilişkin kanun maddesini Taşer, (2006) şöyle aktarmaktadır: "Ĕğitim Bakanlığı, İstanbul Üniversitesine alınmış ve alınacak yabancı hocalarla müddeti 10 yılı geçmemek üzere lüzum görülecek sürelerle anlaşma yapılır" demektedir.

Mülteci profesörlerin iş anlaşmalarının şartları Maarif Vekâleti ile Prof. Malche, Prof. Schwartz ve Prof. Rudolf Nissen arasında görüşülüp kararlaştırılmıştır (Neumark, 2017). 1933-1951 yılları arası Türkiye'de hocalık yapan Fritz Neumark anılarını yazdığı "Boğaziçi'ne Sığınanlar" kitabında (2017) konuyla ilgili olarak "Türk profesörlerin Alman profesörlerinin maaşının yarısını hatta dörtte birini aldı ̆̆ $\_$" yorumunu yapmakta, maaşlarının genelde 500-600 lira olduğunu ancak Türk lirasının alım gücünün resmi kurlardan yüksek olduğunu belirtmekte maaşların yeterli olduğunu söylemektedir. Ayrıca Kontrat sürelerinin genelde 5 yıl olarak düzenlendiğini, Türk dilinin en kısa sürede öğrenilmesini ve Türkçe yayın yapılmasının istendiğini söylemektedir.

$\mathrm{Bu}$ dönemde mimarlar, şehir plancıları, Clemens E. Bosch gibi nümizmatlar (sikkeleri inceleyen uzmanlar), Sümeroloji uzmanları, doğu dilleri uzmanları, Sinologlar, kütüphaneciler, filoloji uzmanları, Türkologlar, zoologlar, botanikçiler, müzisyenler, tiyatrocular, kemancılar, heykeltıraşlar, iktisatçılar, hukukçular, kamu sağlığı uzmanları, doktorlar, diş hekimleri, astronomlar, kimya profesörleri, biyokimya ve biyoloji profesörleri, farmakologlar, fizikçiler, matematikçiler, felsefeciler bir yandan çığır açıcı eserler bırakırken diğer yandan öğrenci yetiştirip disiplinleri yerleştirip kalıcı olmasını sağladılar. Köy köy gezip sağlık taraması yapmak, halen kullanılan binalarımızın planlarını çizmek, konservatuvarlarımızı geliştirmek, vergi kanunumuzu modernleştirmek, tıbbi altyapımızı güçlendirip öğrenci yetiştirmek gibi etkilere yol açmışlardır. Fen ve sosyal bilimlerde, güzel sanatlarda ülkemizi dönüşüme uğratmış, kamu sağlığı, kütüphanecilik, müzecilik, hukuk, mühendislik ve yönetim uygulamalarını yeniden tasarlayıp biçimlendirmişlerdir. Ayrıca arkeoloji ve filoloji alanında çı̆̆ır açıp tablet, kitabe ve yazıları çevirmişlerdir. Ama belki de en önemlisi bilimsel kültürün, bilimsel metodolojinin öğretilmesi, yerleşmesi anlamındaki katkıları ile gelecek için öğrenci yetiştirmeleri olmuştur (Namal, 2012).

1950-1960 arası ABD'den de eğitimci bilim insanları Maarif Vekâleti tarafından Türkiye'ye davet edilmiş ve Türk Eğitim sistemi hakkındaki görüşlerini rapor halinde sunmuşlardır. ABD Florida Üniversitesi Eğitim Koleji İlkokul Bölümü Başkanı Kate Wofford, İlkokul Programı'nın geliştirilmesi ve eksik kalan yanlarının belirlenmesi için Türkiye'ye davet edilmiştir. Türkiye'nin birçok ilini dolaşmış, ilk öğretmen okulları ve köy enstitülerini dolaşmış, gördüğü Türk eğitim sistemindeki aksaklıkları, “Türkiye Köy İlkokulları Hakkında Rapor" adıyla 1952 yılında tamamlayarak Maarif Vekâleti 'ne sunmuştur. 38 köy okulunu ziyaret etmiş 22 konferans vermiş, köy öğretmeni, müfettiş, Köy Enstitüsü ve öğretmen okulu öğretmenlerine anketler uygulamış, gittiği köylerde muhtarlarla görüşerek çalışmalarını “Türkiye Köy İlkokulları Hakkında Rapor"(Wofford, 1952) adıyla sunmuştur (Mar, 2018: 14).

John Rufi, Türkiye'de orta dereceli okullarda uygulanan programın amaç, başarı ve problemlerini araştırmak amacıyla Ekim 1951'de Türkiye'ye gelerek Haziran 1952'ye kadar birçok ilde ortaöğretim kurumlarında incelemelerde bulunup, öğretmen ve yöneticilerle görüşmüş, toplantılara katılmıştır. Türkiye'de Orta Öğretim, Müşahedeler, Problemler ve 
Tavsiyeler" adıyla Maarif Vekâleti 'ne bir rapor sunmuştur. Ortaokul ve lise programlarının yoğunluğuna dikkat çekmiş, öğrencilerin ders dışı etkinliklere zamanı olmadığını, öğrencide yorgunluk oluştuğunu, sinavlar ve öğrencilere ders seçme imkânı verilmemesinin, başarısızlığın nedenleri olarak belirtilmiştir (Tan, 1992).

Maaske (1955), 1950 yılında Türkiye’ye gelmiş, incelemelerini “Türkiye'de Öğretmen Yetiştirme Hakkında Rapor," düzenlemiştir. Beşinci Eğitim Şurası'na da katılmıştır. Öğretmen okullarına öğrenci alınırken yalnız bilgiye değil, bir öğretmende bulunması gereken vasıflara da bakılmasını, öğretmenlerin yüksekokul mezunu olmalarını, öğretmen okullarının kitaplıkları olmasını, öğretmenlere uygulanacak meslek, genel kültür ve özel meslek derslerinin dengeli bir dağılımın sağlanmasını ve öğretmenlerin hizmet içi eğitimlerle gelişmelerinin sağlanmasını önermiştir (Maaske 1955: 1-5, akt. Marım ve Sam, 2018).

Ekim 1952'den Ağustos 1953'e kadar Maarif Vekâlet'inde müşavir olarak çalışan Beals, Rehberliğin Lüzumu Hakkında Rapor" hazırlamış ve Türkiye' de sınıfta kalmanın yüksekliğinden bahsedilmiştir. İllerde rehberlik kurulları oluşturarak onlara rehberlik ve danışma faaliyetleri için plan ve rapor hazırlatmıştır (Tan 1992: 35).

Ekim 1952'de Tomkins, ortaokul ve liselerde incelemelerde bulunmuş, incelemelerini "Türkiye Cumhuriyeti Orta Dereceli Okullarda Organizasyon, İdare ve Teftiş " isimli raporunda toplamış, ortaöğretimdeki program değişikliğinin zorunluluğuna dikkat çekmiştir. M.Costat 1951 yılında Türkiye'ye gelmiş ve Türkiye'de Meslek Okulları Hakkındaki görüşlerini rapor halinde vermiştir. Ev ekonomisi uzmanı Elizabeth S. Gorvine, 1955'de Türkiye'ye gelmiş ve iki yıl Türkiye'de kız teknik öğretiminin bütün aşamalarıyla ilgili incelemelerde bulunmuş, Altıncı Maarif Şurası'na şura üyesi olarak katılmış, gözlem ve önerilerini rapor halinde sunmuştur (Marım ve San, 2018:23).

$\mathrm{Bu}$ raporlar, Türkiye Cumhuriyeti'nin eğitim seferberliğinde önemli bir rol oynamıştır. Raporlarda ortak noktalar; Türk okullarında ders sayısının ve haftalık ders saatinin fazla olduğu, öğrenciye seçim hakkı verilmediği, okullarda rehberlik hizmetlerinin kurulmasını, sınav sisteminin gözden geçirilmesini ve mesleki eğitimin önemi vurgulanmıştır.

\section{Sonuç ve Öneriler}

Bu araştırma, Cumhuriyet'in 1923-1960 arası dönemde eğitimde yapılan reformist hareketleri, izlenen politikaları, yabancı eğitim uzmanlarının Türk Millî Eğitimi hakkındaki görüşlerini yansıtmak için yapılmıştır. Araştırma sonuçlarına göre; Cumhuriyetin ilk döneminde eğitimcilerin sayısal azlığı, kaynak eksikliği, eğitime ayrılan bütçe ve imkânların kısıtlı olması önde gelen sorunlardı. Bu dönemde en önemli hedef, okul sayısını arttırmak ve cumhuriyet idealine bağlı, çağın gereklerine uygun nesiller yetiştirmekti. Eğitimde öncelikle okur- yazar seviyesinin artırılmasına yönelik mücadele, müfredat geliştirme ve öğretmen yetiştirme gibi konularda çalışmalar yoğunlaşmıştır. Eğitim ve öğretimin düzenlenmesi ile ilgili yasa ve genelgeler çıkarılarak yapılacak düzenlemelerin yasal dayanaklarının olmasına dikkat edilmiştir. 1932'den itibaren üniversitelerin kuruluşu ve reform hareketleri, yabancı uzmanların Türkiye'ye çağrılması, onlardan Türk eğitim sistemi hakkında görüşler 
sunmalarının istenmesi, eğitimde yenileşme hareketinin önemli adımlarıdır. Türkiye Cumhuriyeti'nin kurucuları, tüm imkânsızlık ve olumsuzluklara rağmen Üniversite Reformu'nu yapmışlar, yeni üniversitelerin kurulması ve meslek liselerinin arttırılması için büyük çaba harcamışlardır. Öğretmen ihtiyacının giderilmesinde köye hizmet edecek donanıma sahip öğretmenlerin yetiştirilmesi için Köy Enstitülerinin kurulması Türkiye' de çok önemli adımlardan biridir.

Devleti oluşturan bütün kurumlarda birçok yeni düzenlemelere ve bunun sonucu olarak değişmelere gidilmiştir. Cumhuriyetin ilk ve sonraki dönemlerinde getirilen eğitim uzmanları Türk okullarında sınıfta kalan, devamsızlık yapan ve okulu terk eden öğrencilerin sayısının fazla olduğunu, bilhassa Amerikalı uzmanların milli eğitim politikalarımızın uygulanması aşamasındaki başarısızlıkların temelinde, istikrarsızlık ve kaynak yetersizliğinin yattığını belirtmeleri eğitimdeki yenileşme hareketlerine bir ivme kazandırmıştır. Ancak, yabancı uzmanların başka bir toplumdan gelmeleri, Türkiye'nin manevi değerlerini çok da iyi kavrayamadıkları bir gerçektir (Marım ve Sam, 2018; Tangülü, Karadeniz ve Ateş, 2014).

Türk Millî Eğitiminin çağdaş eğitim temellerine oturtulması ile ilgili uygulamalar, kanun ve yönetmeliklerle desteklenerek yapılmıştır. Eğitimde, Cumhuriyet dönemindeki hızlı yenileşme hareketi, Türkiye'de kalkınmanın lokomotifini oluşturmuştur. Geçmişteki uygulamaların millî kültürümüze uygun, akılcı, bilimsel nitelikte olması, iyi örneklerin devam ettirilmesi ile mümkündür. Bu konuda oluşturulan politika ve stratejilerin uluslararası standartlar çerçevesinde olması gereklidir.

\section{Kaynakça}

Akarsu, F. (2000). Cumhuriyet dönemi eğitim uygulamaları. Bir özet değerlendirme. Ĕ̆gitim ve Bilim. 25(116),3-7.

Akdemir, A.S. (2013). Türkiye'de öğretmen yetiştirme programlarının tarihçesi ve sorunları. Turkish Studies, 8(12). 15-28.

Akgün, S. ve Uluğtekin, M. (1989), Misakı maarif, 1(3). 285-34 <https://dergipark.org.tr/tr/pub/ankuayd/issue/1877/22775

Akyüz, Y. (2010). Türk eğitim tarihi (M.Ö. 1000-M.S. 2010),18. Baskı. Ankara: Pegem A.

Altın, H. (1964). II. Meşrutiyetten cumhuriyete İsmail Hakkı Baltacıoğlu ve onun eğitim ve eğitimci kavramları ile ilgili düşünceleri. Pedagojide İhtilal, İstanbul, 219-251.

Antel, S. C. (1939). Maarifimiz ve meseleleri, İstanbul: Remzi Kitabevi

Antel, S.C. (2015). Maarif teşkilatı hakkında bir layiha. 1926. Eğitim İş Kültür Yayınları: Ankara.

Arı, A. (2002). Tevhid-i tedrisat ve laik eğitim. G.Ü. Gazi Eğitim Fakültesi Dergisi. 22 (2), 181192.

Aslan, C. (2014), Erken cumhuriyet döneminde eğitim bilimleri alanında yurt dışına öğrenci gönderilmesi olgusu (1923-1940).( Doktora tezi), Ankara Üniversitesi, Eğitim Bilimleri Enstitüsü 
Ayas, N. (1948). Türkiye cumhuriyeti milli eğitimi (Kuruluşlar ve tarihçeler). Ankara: Milli Eğitim Bakanlığ1 Yayınevi.

Aytaç, K. (1979). Baltacıoğlu'nun hayatı ve faaliyetleri, DTCF Araştırma Dergisi, C. IX, 165-190.

Baltacığlu, İ. , H, (1942). İçtimai mektep. Ankara: Maarif Matbaası.

Başgelen, N. (2011). Eskiçă̆ bilimleri alanında ilk yetişenler, İstanbul: Arkeoloji Sanat Yayınları.

Bedri , A.(1933). Ilk tedrisat düsturu, İstanbul: Vakit Matbaası

Binbaşıŏlu, C. (1995). Türkiye'de eğitim bilimleri tarihi, İstanbul: Milli Eğitim Basımevi:

Budak, Ş. (2003). Atatürk'ün eğitim felsefesi ve geliştirdiği eğitim sisteminin değiştirilmesi, Milli Eğitim Dergisi, sayı: 160

Budak, L ve Budak, Ç. (2014). Osmanlı İmparatorluğu'ndan Türkiye Cumhuriyeti'ne ilkokul programları (1870-1936). Türkiye Sosyal Araştırmalar Dergisi (TSA ), 18(1), 51-68.

Cicioğlu, H. (1985). Türkiye Cumhuriyeti'nde ilk ve ortaöğretim, Ankara Üniversitesi Eğitim Bilimleri Fakültesi Yayınları no:140,

Cumhuriyet. (13 Mayıs 1938). bütçemizin encümende aldığı son şekil https://www.gastearsivi.com/gazete/cumhuriyet/1938-05-13/1

Çelebi, N. (2003). Dil ve Tarih-Coğrafya Fakültesi'ndeki mülteci profesörler. Ankara Üniversitesi Dil ve Tarih Coğrafya Fakültesi Dergisi, 43 (1), 259-272.

Çelebi, N. ve Asan, T. (2016). Köy enstitülerinde uygulanan demokratik eğitim çalışmaları ve istenen birey anlayışı. 978-605-318-393-8 E-ISBN'li “Ĕğitim Yönetimi Araştırmaları" Ankara: PegemA.

Çelebi, N. ve Asan, H.T. (2013). Cumhuriyet'in ilk yıllarındaki (1923-1946) insan/birey yetiştirme paradigmasının son Osmanlı birikimi ile karşılaştırılması, Ĕ̆itim ve Öğretim Araştırmaları Dergisi, 2(1). 140-148.

Çetin, K, ve Gülseren, Ö,H. (2003).Cumhuriyet dönemi eğitim stratejileri. Milli Ĕ̆itim Dergisi. Sayı:160

Demirtaş, B. (2008). Atatürk döneminde eğitim alanında gelişmeler. Akademik Bakış Dergisi, 1(2). 155-166.

Dewey, J. (1939). Türkiye maarifi hakkında rapor. Devlet Matbaası, İstanbul

Dik, E. (2016).Türkiye'de erken Cumhuriyet Dönemi'nde (1923-1930). Köy sorunu. Ankara Üniversitesi SBF Dergisi, 71(3), 693 - 729.

Er, E. (2019). Eğitimin tarihi temelleri. Ĕ̆gitime giriş. (Edit. T. Çalık, M. Metin Arslan). Ankara: Pegem A. 99-124.

Erdem, A.R. (2012). Atatürk'ün liderliğinde üniversite reformu: Yükseköğretim ve bilim tarihimizde dönüm noktası. Belgi Dergisi. Y11. 4, 376-388.

Geraskof, M. (1933). Talim ve tedriste kendi kendine faaliyet prensibi, çev. Hasip Ahmet, İstanbul: Remzi Kitabevi 
Gerede, H. (2020). Hitler Almanyası'nda Berlin sefirliği hatıralarım (1939-1942), Ankara: İş Bankası Yayınları.

Güler, A. (2004), Türk eğitim politikalarının tarihsel süreci. Ankara: Yeryüzü Yayınları.

Gökçe, F. (2009). Değişme sürecinde devlet ve eğitim. Ankara: Pegem Akademi.

Harbison, F. (1973). Eğitim planlaması ve insan kaynă̆ını geliştirme. Çev. Hıfzı Doğan, Ankara: Milli Eğitim Basımevi.

Hesapçıŏlu, M. (2009), Türkiye'de Cumhuriyet Dönemi'nde eğitim politikası ve felsefesi, M.Ü. Atatürk Ĕ̆itim Fakültesi Eğitim Bilimleri Dergisi, Sayı: 29, 121-138.

Hirsch, E. (2008). Anılarım. Ankara: TÜBİTAK Popüler Bilim Kitapları, (11.basım).

İçke, A. (2015). Atatürk dönemi yurt dışı eğitimi, (Doktora tezi), Ankara Üniversitesi, Sosyal Bilimler Enstitüsü.

Kalayc1, N. (2004) Cumhuriyet döneminde ilköğretim, İstanbul, Milli Eğitim Bakanlığı Yayınları,

Kanad, H .F.(1941). Pedagoji, Ankara. Gazi Terbiye Enstitüsü Neşriyatı.

Kansu.N.A. (1929). Pedagoji tarihi. İstanbul. Devlet Matbaası.

Kapluhan, E. (2012). Atatürk dönemi eğitim seferberliği ve köy enstitüleri. Marmara Coğrafya Dergisi, sayı: 26, s. 172-194.

Kartal, Ö. (2016). Erken cumhuriyet döneminde yabancı uzman raporlarına göre Türk eğitim sisteminin ezbercilik sorunu. Journal of Research in Education and Soctety 3(1), 42-59.

Kıral, B. (2020). Nitel bir veri analizi yöntemi olarak doküman analizi. Sosyal Bilimler Enstitüsü Dergisi. Journal of Social Sciences Institute. say1.15, 170-189, ISSN: 2147-8406.

Maarif Vekilliği. (1939) Amerikan heyeti raporundan maarif işleri, İstanbul.

Malche, A. (1939). İstanbul üniversitesi hakkında rapor. İstanbul: Devlet Matbaas1.

Marım, Y. ve Sam, R. (2018). 1950-1960 arası Amerikalı uzman raporları bağlamında Türk eğitim sistemine çizilen yol haritası. Kaygı, 11-33.

Möckelmann, E. (2020). İkinci vatan Türkiye, Ernst Reuter'in Ankara yılları (Çev. A.Arpad). Ankara: İş Bankası Yayınları.

Mütercimler, E. (2016). Fikrimizin rehberi. Alfa Yayınları, (10. Baskı), İstanbul

Namal, Y. ve Karakök, T. (2011) Atatürk ve üniversite reformu (1933), Yükseköğretim ve Bilim Dergisi/ Journal of Higher Educational Science, 1 (1), 27-35

Nami, K. (1934). Muallimin meslek ahlakı. Milli Eğitim Matbaası: İstanbul.

Namal, Y. (2012). Türkiye'de 1933-1950 yılları arasında yükseköğretime yabancı bilim adamlarının katkıları. Yükseköğretim ve Bilim Dergisi/Journal of Higher Education and Science. 2(1),14-19, DOI: 10.5961/jhes.2012.028

Neumark, F. (2017). Boğaziçine sı̆̆ınanlar (Çev. Şefik Alp Bahadır), İstanbul: Kopernik Kitap.

Ortak, Ş. (2004). Atatürk dönemi eğitim politikalarında yabancı uzman raporlarının etkileri, (Doktora Tezi),Erzurum, Atatürk Üniversitesi, Atatürk İlkeleri ve İnkılap Tarihi Enstitüsü. 
Öksüz, H. ve Köksal, Ü. (2018). Amerikan belgeleri 1şığı altında cumhuriyetin ilk yıllarında Türkiye' de eğitim, Akademik Bakış Dergisi, 11(23).

Özata, M. (2007). Atatürk, bilim ve üniversite. Ankara: TUBİTAK Popüler Bilim Kitapları.

Özodaşık, M. (1999). Cumhuriyet dönemi yeni bir nesil yetiştirme çalışmaları 1923-1950, Konya: Cizgi Kitabevi.

Öztürk, C. (2007). Atatürk devri öğretmen yetiştirme politikası. Ankara. Türk Tarih Kurumu Yayınları.

Patri, A. (1934). Yarınki mektebe doğru.( Çev. Kazım Nami), İstanbul: Devlet Matbaası,

Reisman, A. (2011). Nazizmden kaçanlar ve Atatürk'ün vizyonu. Çev. Gül Çağalı Güven, Ankara: İş Bankası Kültür Yayınları,( 2. Baskı).

Rufi, Jehn, J. (1956). Türkiye'de ortä̈ğretim ( Müşahedeler, problemler, tavsiyeler). Ankara: Maarif Basımevi.

Sönmez, V. (1996). Eğitim felsefesi. Ankara: Pegem A.

Şahin, M. ( 1996). Türkiye'de öğretmen yetiştirme uygulamalarında yabancı uzmanlarm yeri, (Doktora tezi), Dokuz Eylül Üniversitesi. İzmir. Atatürk İlkeleri ve İnkılap Tarihi Enstitüsü.

Şahin, M.(2016). Hınes-Kemmerer'in Türk eğitim sistemi hakkındaki görüşleri ve etkileri. Uluslararası Sosyal Araştırmalar Dergisi. 9 (47),294-300.

Şarman, K.(2021). Türk Promethe'ler. İstnbul. İş Bankası Kültür Yayınları. (6.Baskı).

Tan, Hasan (1992). Psikolojik danışma ve rehberlik teori ve uygulama, İstanbul: MEB Yayınları.

Tangülü, Z., Karadeniz, O, Ateş ,S. ( 2014). Cumhuriyet dönemi eğitim sistemimizde yabancı uzman raporları (1924-1960), 9(5).1895-1910. Turkish Studies.9 (5)

Taşdemirci, E. (2010). Türk eğitim tarihi. Ankara: Gündüz Eğitim ve Yayıncılık.

Taşer, S. (2006). Cumhuriyet döneminde üniversite eğitiminin yeniden düzenlenmesi-1933 üniversite reformu ve getirdikleri. (Yüksek Lisans Tezi), Konya: Selçuk Üniversitesi, Sosyal Bilimler Enstitüsü.

T.C. Maarif İşleri (1939). Amerikan heyeti raporundan: Maarif işleri. İstanbul: Devlet Basımevi.

Tezel,Y.(2015).Cumhuriyet döneminin iktisadi tarihi (1923-1950). İstanbul: Türkiye İş Bankası Kültür Yayınları.

Tekeli, İ. ve İlkin, S. (2014). İkinci dünya savaşı Türkiyesi (3.Cilt), İstanbul: İletişim Yayınları.

Ülken, H. , Z. (2014). Eğitim felsefesi. İstanbul: Doğu-Batı Yayınları.

Yalçın, A. (2019). Cumhuriyet dönemi yabancı eğitim uzmanlarından John Dewey ve Beryl Parker'ın raporlarında "iyi vatandaş" algısı. Eğitimde Kuram ve Uygulama. 15 (1), 59-70.

Yıldırım, A. ve Şimşek, H. (2016). Sosyal bilimlerde nitel araştırma yöntemleri. Ankara: Seçkin.

Zürcher, E. J. (2006). Modernleşen Türkiye'nin tarihi. Çev. Y. Alogan. İstanbul: İletişim Yayınları 